\title{
Enduring Influence of Elizabethan Ophthalmic Texts of the 1580s: Bailey, Grassus, and Guillemeau
}

\author{
Christopher T. Leffler ${ }^{*}, 1$, Stephen G. Schwartz ${ }^{2}$, Byrd Davenport ${ }^{1}$, Jessica Randolph ${ }^{1}$, \\ Joshua Busscher ${ }^{1}$ and Tamer Hadi ${ }^{1}$ \\ ${ }^{1}$ Department of Ophthalmology, Virginia Commonwealth University, 401 N. 11th St., Box 980209, Richmond, VA 23298, \\ $U S A$ \\ ${ }^{2}$ Bascom Palmer Eye Institute, University of Miami Miller School of Medicine, 311 9th Street North, \#100; Naples, FL \\ 34102, USA
}

\begin{abstract}
Three English ophthalmic texts of the 1580s were frequently republished: 1) Walter Bailey's A Briefe Treatise Touching the Preseruation of the Eie Sight, 2) The Method of Phisicke, an adaptation of the medieval treatise of Benevenutus Grassus, and 3) A Worthy Treatise of the Eyes, a translation of Jacques Guillemeau's treatise. Their history is intertwined through composite publications, some of which lacked clear attribution. At least 21 editions incorporated these texts. Although not previously realized, major elements of all 3 works are found in Two Treatises Concerning the Preseruation of Eie-sight, first published in 1616. To preserve eyesight, Bailey recommended eyebright (Euphrasia officinalis), fennel (Fceniculum vulgare), and a moderate lifestyle incorporating wine. In the works of Grassus and Guillemeau, cataracts were believed to lie anterior to the 'crystalline humor,' and were treated by the 'art of the needle,' or couching. Links are found between Grassus, Guillemeau, and eighteenth century glaucoma concepts. Although one of his students has traditionally received credit, it was English oculist John Thomas Woolhouse who first combined the early concepts and used the term glaucoma to describe the palpably hard eye in the early eighteenth century. The three primary ophthalmic texts of 1580s England influenced ophthalmic thought for over a century.
\end{abstract}

Keywords: Alcohol, cataract, couching, eyebright, glaucoma, ophthalmology.

\section{INTRODUCTION}

Britain in the $1580 \mathrm{~s}$ is generally remembered for Elizabethan rule and the defeat of the Spanish Armada. Ophthalmologists might remember this period for three texts which were repeatedly published over the next century, and, therefore, appear to have had a major impact on ophthalmic thought. A Brief Treatise Touching the Preseruation of the Eie Sight, written by English physician Walter Bailey in 1586 [1], is considered the first English ophthalmology monograph [2]. Method of Physicke, first published in 1583 [3], and considered to be the first medical text in English [4], had major ophthalmic chapters adapted from the medieval treatise of ophthalmic practitioner Benevenutus Grassus [5, 6]. Finally, A Worthy Treatise of the Eyes [7], the 1587 translation of Jacques Guillemeau's ophthalmic treatise [8], is considered the first complete ophthalmic text in English.

These works, and composite texts which incorporated them, were reviewed to uncover the major concepts in British ophthalmic thought during this period. Bibliographic information and the history of the words 'glaucoma' and 'lens' were researched using reference works [9-11], review

*Address correspondence to this author at the Department of Ophthalmology, Virginia Commonwealth University, 401 N. 11th St., Box 980209, Richmond, VA 23298, USA; Tel: (804) 828-9315; Fax: (804) 828-1010;

E-mail: chrislefflermd@gmail.com articles [2, 5, 12], and digital resources [13-15]. Word frequency analysis of the texts using an online analysis tool was performed to uncover the major concepts (Table 1) [16].

\section{PRINCIPAL TEXTS}

The Brief Treatise Touching the Preseruation of the Eie Sight, by Walter Bailey (1529-1592), was published in 9 editions between 1586 and 1673 (either alone $[1,17]$ or in a composite text [7, 18-20], Table 1, Fig. 1), and, if released today, would be considered a work in preventive medicine. Bailey described preparation of 'drinke' and medicines containing eyebright (Euphrasia officinalis), fennel (Faniculum vulgare), and other types of 'herbe,' such as vervain (Verbena officinalis). Given the prominence accorded to wine, beer, ale, and mead (honey wine), alcohol was likely the bioactive portion of the Elizabethan medical potion. Bailey mentioned that a new form of brewing ale had been developed. He recommended moderation regarding medicines, alcohol, sex, diet, sleep, exercise, and emotions $[7]:^{1}$

\footnotetext{
'... gentle medicines taken in due time, do great good to the sight...',

'...wine is not inconvenient, ...so it be moderately taken',
}

\footnotetext{
${ }^{1}$ No pagination was provided for Bailey's treatise.
} 
Table 1. Frequently-mentioned terms and publication years of ophthalmic texts of the 1580 .

\begin{tabular}{|c|c|c|c|c|}
\hline & $\begin{array}{l}\text { Years of } \\
\text { Publication }\end{array}$ & $\begin{array}{c}\text { A Briefe Treatise Touching the } \\
\text { Preseruation of the Eie Sight. } \\
\text { By Walter Bailey [1] }\end{array}$ & $\begin{array}{c}\text { The Methode of } \\
\text { Phisicke. Adapted from } \\
\text { Benevenutus Grassus (1100s?) } \\
\text { by Philip Barrough [3] }\end{array}$ & $\begin{array}{c}\text { A Worthy Treatise of the } \\
\text { Eyes. Translation of Jacques } \\
\text { Guillemeau's treatise by } \\
\text { Anthony Hunton (1560?-1624) } \\
\text { [7] }\end{array}$ \\
\hline $\begin{array}{l}\text { Frequent Concepts } \\
(>0.1 \%)\end{array}$ & & $\begin{array}{l}\text { Sight, eyebright, wine, drinke, } \\
\text { fenill, meate, herbe, preserue, } \\
\text { medicines, ale, powder, water, } \\
\text { beere, clear, sleepe, compounded, } \\
\text { roots, iuices, sugar, dimness, } \\
\text { head, meade, seeds, egge, old, } \\
\text { sirup, stomacke, boyle, clense, } \\
\text { seeds, turnep, veruaine. }\end{array}$ & $\begin{array}{l}\text { Cure, patient, pouder, tunicle, } \\
\text { humours, cataract, paine, egge, } \\
\text { water, plaister, needle, braine, } \\
\text { purge, pannicle, cautery, beaten, } \\
\text { melancholy, healed, flaxe, } \\
\text { electuary, pilles, fleume [phlegm], } \\
\text { corrupt, iuyce, stomach, hard, dry. }\end{array}$ & $\begin{array}{l}\text { Humor, eye-lidde, cure, greeke, } \\
\text { medicines, latin, disease, sight, } \\
\text { drie, naturall, skinne, vlcer, cut, } \\
\text { bloud, harde, paine, } \\
\text { inflammation, cataract, spirites, } \\
\text { thicke, moisture. }\end{array}$ \\
\hline Primary text alone*. & & 1586, 1602, 1654, 1673. & $\begin{array}{l}1583,1590,1596,1601,1610 \\
1617,1624,1634,1639,1652\end{array}$ & \\
\hline $\begin{array}{c}\text { A Worthy Treatise of the } \\
\text { Eyes [7]. }\end{array}$ & 1587. & Included. & & Included. \\
\hline $\begin{array}{l}\text { Two treatises concerning } \\
\text { the preseruation of eie- } \\
\text { sight. John Barnes } \\
\text { (publisher) [18-19]. }\end{array}$ & $\begin{array}{l}1616,1626 \\
1633 .\end{array}$ & Included. & Extended excerpts. $\dagger$ & Extended excerpts. $\dagger$ \\
\hline $\begin{array}{c}\text { Richard Banister. A } \\
\text { treatise of one hundred } \\
\text { and thirteene diseases of } \\
\text { the eyes, and eye-liddes } \\
\text { [20]. }\end{array}$ & 1622. & Included. & & Included. \\
\hline $\begin{array}{l}\text { William Read. A Short } \\
\text { but Exact Account Of all } \\
\text { the Diseases Incident to } \\
\text { the Eyes [23]. }\end{array}$ & 1706,1710 & & & Included. \\
\hline
\end{tabular}

*Only one reference is listed for multiple editions which varied only in spelling.

As the 1602 edition of Bailey was labeled the sixth edition, there may be other editions which have been lost.

$\dagger$ Text in publication year drew heavily upon reference text without attribution.

'As modest use of venus [sex] performed in the fear of God in due time...is to be allowed',

'And he that will continue his sight good, must be careful of over plentiful feeding',

'sleep taken in the night is best as most natural',

'Exercises are needful',

'immoderate sorrow, fearfulness, and all vehement affections are forbidden in all affects...'

Throughout this paper, we have used modern spelling in quoted passages to enhance clarity. Bailey's recommendation of a moderate lifestyle contrasts with the purging and bloodletting of his contemporaries (as discussed below), and, in comparison, would still be considered healthy today.

Methode of Physicke contained lengthy chapters on eye diseases, adapted, as noted above, from the manuscript of Benevenutus Grassus. Scholars believe that Grassus, an ophthalmic healer and professor of the $12^{\text {th }}$ or $13^{\text {th }}$ centuries, was based primarily in France and Italy, although he travelled widely [21]. As evidenced by continued publication after 500 years, Grassus' teachings had an extended influence on ophthalmic thought. Grassus' work offers the perspective of an experienced and practical eye surgeon. Between 1583 and 1652, his description of "the art of the needle" to cure cataracts was published in 10 primary text editions [3], plus 3 composite works [18-19] (Table 1): ${ }^{2}$

'.... while the diseased party is fasting,...cause him to sit overthwart a stool in riding fashion, and plant yourself likewise on the same stool face to face against him, and bid him, hold his sound eye closed shut...Then with your left hand lift up the over eyelid, and with your other hand put in the needle made therefore, on the side furthest from the nose: and subtly thirl the tunicle salvatrice [dexterously bore through the eye coats], writhing always your fingers to and fro, till you touch the corrupt water (which is the cataract) with the point of the needle; and then begin by little and little to remove that water from before the sight to the corner of the eye, and there keep it with the point of your needle, the space of three minutes of an hour, and then remove your needle easily from it. And if it happen that it riseth up again, bring it back the second time... Cause him to shut his eye, and apply thereto a plaster of flax and the white of an egg, and cause him to lie in his bed nine days together...' 


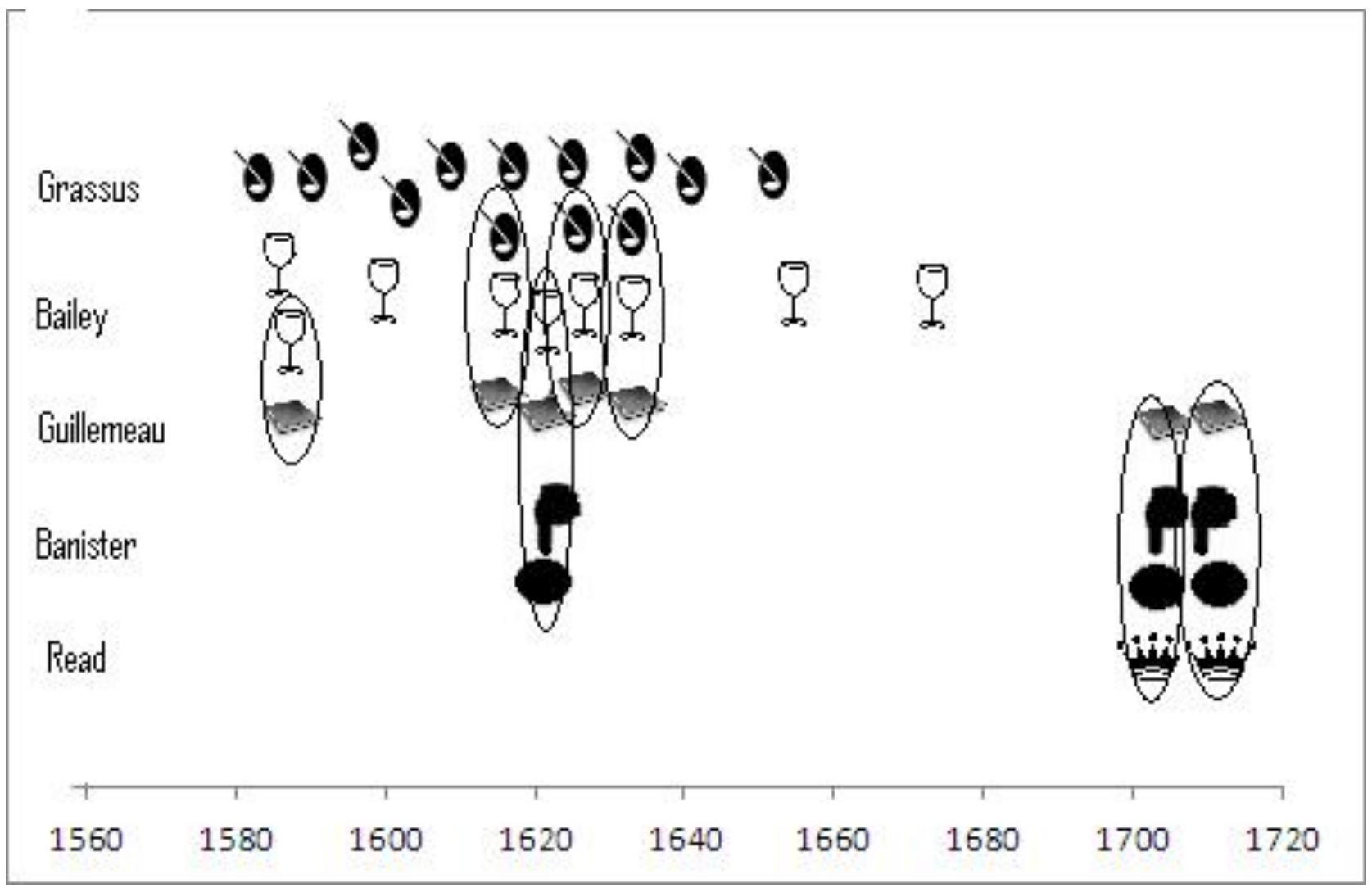

Fig. (1). Publication year of principal ophthalmic texts of the 1580's (Bailey [1, 17], Grassus [3], and Guillemeau [7]), and composite texts [18-20, 23]. Icons representing the components of composite texts are circled. The eye being couched represents Grassus' surgical text. The wine glass represents Bailey's Treatise, which recommended a moderate lifestyle incorporating wine. The book represents Guillemeau's encyclopedic and comprehensive ophthalmic treatise. The finger near the eye represents Banister's treatise, which noted the poor prognostic significance of the palpably hard eye. The crown icon represents the text of William Read, the royal oculist.

Throughout, the author recommends making a surgical dressing, or 'plaister,' from egg white on flax, the fiber from which linen is made. Medicines are given as a powder, an electuary (a paste), or 'pills.'

Besides cataract, the other major ailment is the 'pannicle,' which might include corneal pannus or scarring, pingueculum, pterygium, phlyctenule, leukoma, and conjunctival nevus [3]. ${ }^{3}$ Despite its recommendation by 'many boisterous fellows,' cautery 'with a hot iron' should not be applied to a condition resembling dacryocystitis, which should be treated by incision followed by placement of 'the grain of a fitch [Vicia sativa]' [3]. ${ }^{4}$

Worthy Treatise, published in 1587, included Bailey's work, plus the translation of Guillemeau's encyclopedic treatise [7]. The translator obtained Guillemeau's work from his teacher, the famous English anatomist and surgeon John Banister. The translation systematically imported many European concepts, and provided the standard categorization of eye diseases for the next century. Jacques Guillemeau (1550-1613) was the pupil of Ambroise Paré, another prominent French surgeon. Paré and Guillemeau blended classic teachings with the practical knowledge of busy royal surgeons with battlefield experience. Guillemeau most frequently cited Aetius, a sixth-century physician who

${ }^{3}$ Barrough [3], p. 41-44.

${ }^{4}$ Barrough [3], p. 47. practiced in Constantinople. The translation offered Greek and Latin terminology along with colloquial English expressions, and therefore introduced numerous ophthalmic terms into the English language, e.g.: amblyopia, couching, strabismus, myopia, and proptosis [22]. Major sections covered eyelid surgery. The procedure for the eyelid coloboma, involves freshening the edges and suturing, which is described here for the first time [11]. ${ }^{5}$ During the couching of a cataract, one must 'thrust boldly without fear.' $[7]^{6}$ If the cataract should reappear during the procedure, one must break it up with the needle. Some soft cataracts can be broken up with the needle in the beginning, with the thinner parts 'consumed,' an early description of discission [7]. Guillemeau repeats the classic description of aspiration of soft cataracts with a 'hollow needle' but is skeptical about the efficacy [7]. ${ }^{8}$ The translation was published in 4 editions between 1587 and 1710 [7, 20, 23], with 3 additional publications borrowing major portions of the text $[18,19]$ (Table 1, Fig. 1).

As surgeons, both Grassus and Guillemeau promised a 'cure.' Both viewed disease as a result of humors (bodily liquids), sometimes specified as one of the cardinal 'humors' (blood, phlegm, 'melancholy,' or 'choler'), being

\footnotetext{
${ }^{5}$ Hirschberg [11], p. 319.

${ }^{6}$ Guillemeau [7], p. 165.

${ }^{7}$ Guillemeau [7], p. 168

${ }^{8}$ Guillemeau [7], p. 168.
} 


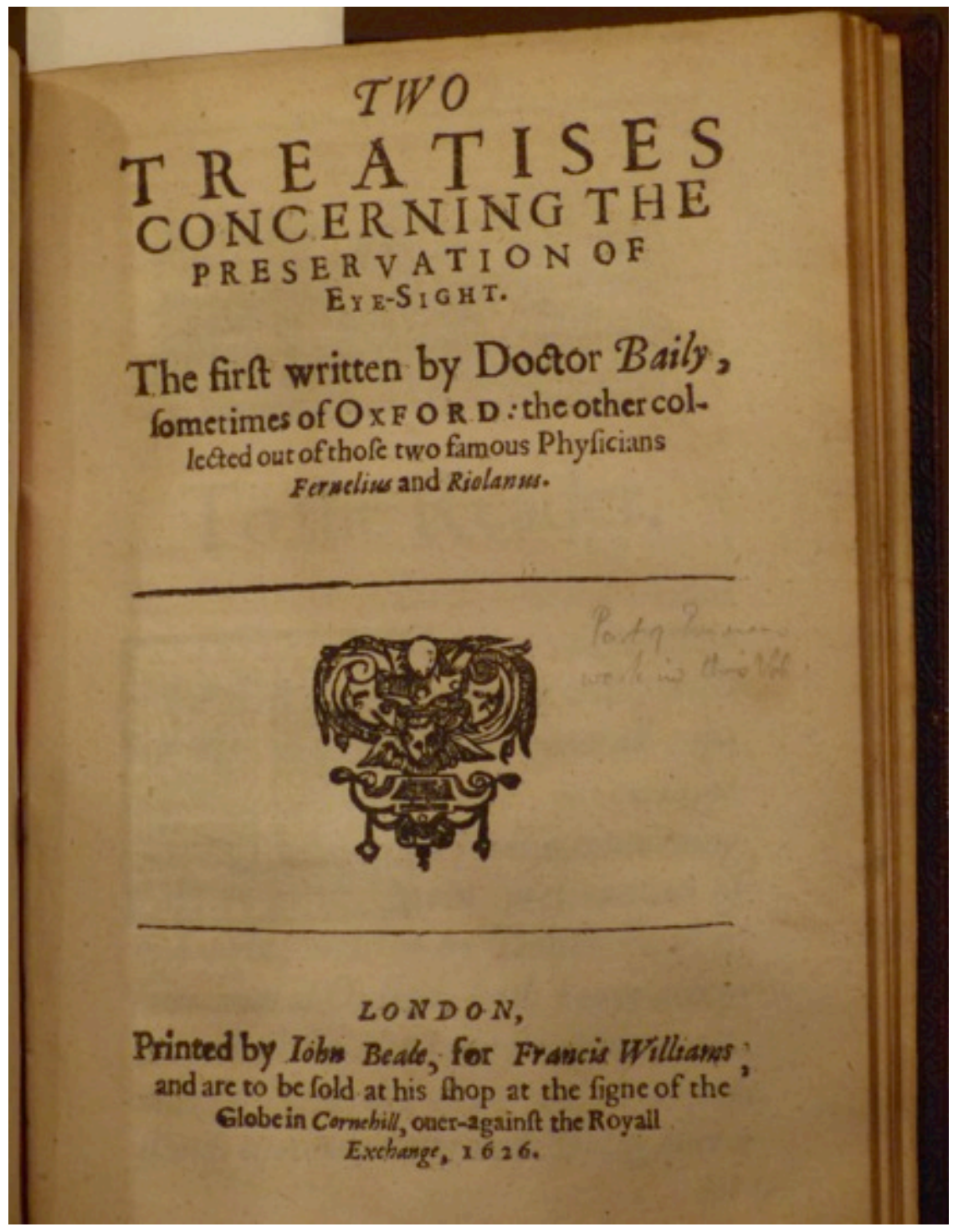

Fig. (2). Title page to Two Treatises, appended to William Vaughan's Directions for Health in 1626 [19]. This composite text incorporates major elements of all three principal ophthalmic texts of the 1580's (Bailey [1], Grassus [3], and Guillemeau [7]).

superfluous, corrupt, thick, or dry. This understanding results in Grassus' recommendation of medicines to 'purge the stomach and brain,' [3] $]^{9}$ and also the application of cautery to the temple or the head. Cautery can be applied to some lesions after surgical removal. Also, on a humoral basis, Guillemeau recommends cutting vessels for blood-letting.

\section{COMPOSITE WORKS}

Several composite works incorporated the above texts. Two Treatises, published in 1616, 1626, and 1633 [18-19] incorporated all three (Fig. 2). The first treatise was a reprint of Bailey's. The second treatise, which has curious origins, is labeled as being from the French physicians Jean Fernel and Jean Riolan. The section on needling the cataract is from the rendition of Grassus in Methode of Phisicke [5]. Our analysis confirmed that much of the work, consisting of a broad overview of eye diseases and recipes for collyria (an eye wash), is a translation of Riolan (see Appendix). We also determined, perhaps for the first time, that the sections on hypopyon, amaurosis, ophthalmia, and pathophysiology of cataract are taken directly from Worthy Treatise, the translation of Guillemeau (see Appendix).

The second composite work was put forward in 1622 by Richard Banister [20], the nephew of the aforementioned anatomist John Banister. The younger Banister's work included Bailey's work, and a reprint of the 1587 translation of Guillemeau. He added his own observations as a dedicated oculist in a section known as Banister's Breviary. Thus, Banister's work was similar to Two Treatises, except that he replaced Grassus' experiences as a practicing oculist with his own.

The composite volume published in 1706 and 1710 by William Read [23], the oculist to Queen Anne, included the translation of Guillemeau and most of Banister's Breviary. Read's accompanying text, Practical Observations, continues to promote the same remedies, such as eyebright and fennel, states that the cataract lies in front of the crystalline humor, and describes the technique of couching.

${ }^{9}$ Barrough [3], p. 45. 
Table 2. Development of concepts related to cataract and glaucoma.

\begin{tabular}{|c|c|c|c|}
\hline & Years of Publication* & $\begin{array}{c}\text { Cataract Described as Anterior } \\
\text { to the Crystalline Humor. }\end{array}$ & $\begin{array}{c}\text { Summary of Concepts Related to the } \\
\text { Modern Conception of Glaucoma. }\end{array}$ \\
\hline \hline $\begin{array}{c}\text { The Methode of Phisicke. Adapted from } \\
\text { Benevenutus Grassus (1100s or 1200s) } \\
\text { by Philip Barrough. [3] }\end{array}$ & $\begin{array}{c}1583,1590,1596,1601,1610, \\
(1616), 1617,1624,(1626), \\
(1633), 1634,1639,1652 .\end{array}$ & Yes. & Some eye disease is incurable. \\
\hline $\begin{array}{c}\text { A Worthy Treatise of the Eyes. } \\
\text { Translation of Guillemeau. [7] }\end{array}$ & $\begin{array}{c}1587,(1616), 1622,(1626), \\
(1633), 1706,1710 .\end{array}$ & Yes. & $\begin{array}{c}\text { Glaucoma is a term implying } \\
\text { incurability. }\end{array}$ \\
\hline Richard Banister's Breviary. [20] & $1622,1706,1710$. & Yes. & The hard eye is incurable. \\
\hline John Thomas Woolhouse. [25, 26] & $1707,1721$. & $\begin{array}{c}\text { Glaucoma implies at most a palliative } \\
\text { cure, and, in some cases, a hard eye. }\end{array}$ \\
\hline
\end{tabular}

*Only one reference is listed for multiple editions which varied only in spelling. (Parentheses indicate years in which a publication drew heavily upon extended excerpt of reference text without attribution).

\section{CATARACT AND THE CRYSTALLINE HUMOR}

The understanding of cataracts in these works reflected classic teachings. The 'crystalline humor', which was the term used to refer to the crystalline lens, was considered the 'seat of vision,' as we might describe the retina today. Given its central importance, the crystalline humor was believed to be in the center of the eye. Banister stated that 'The Crystalline humor is in the middest of the Eyes' [20]. ${ }^{10}$ The cataract, which was displaced by couching, was thought to be a separate structure lying anterior to the crystalline humor [3, 7, 20, 23] (Table 2).

Guillemeau noted that holding the crystalline humor in front of an object magnifies the image, and proposed that this might have been the inspiration for spectacles [7]. ${ }^{11}$ The term lens, Latin for lentil, was used in 1654 in English to describe the crystalline humor, due to its appearance [13]. A spectacle lens, or other convex optical glass, does not resemble a lentil. The only reason to use the term lens to describe such a glass is that its primary purpose is the same as that of the crystalline humor-i.e. to focus an image. Use of the word 'lens' to describe a convex optical glass is therefore an important milestone in the history of ophthalmology because such usage implicitly recognizes the true primary function of the crystalline humor. We have determined that, in English, a use of the term 'lens' to describe an optical glass was published as early as 1644 [24]. Despite this understanding, and many scientific advances in the seventeenth century, the repetition of the classic concepts in Read's treatise of 1710 was by no means exceptional. Mainstream oculists were just beginning to enter into the vigorous debate that would overturn the classic concepts.

\section{GLAUCOMA}

The history of glaucoma involves the unification of three initially separate elements: the incurable optic neuropathy, the hard eye, and the word 'glaucoma.' In Grassus' teaching, recorded in Methode of Phisicke, some types of cataract were considered 'incurable.' For instance, in the 'Gutta Serena,' 'the Nerves optic be oppilate and mortified, so that no medicines can prevail' [3]. ${ }^{12} \mathrm{~A}$ second kind of incurable

\footnotetext{
${ }^{10}$ Banister [20], no pagination.

${ }^{11}$ Guillemeau [7], no pagination.

${ }^{12}$ Barrough [3], p. 40.
}

cataract is green, while a third involves a dilated pupil (Table 2).

Worthy Treatise, the translation of Guillemeau, was the first English text to unite two of the three elements by stating: 'cataracts may be cured, but Glaucoma is incurable.' $[7]^{13}$. According to Guillemeau: '...glaucoma is properly used when the Crystalline humor is dry and thick, and the color of it is green...' [7]. ${ }^{14}$

Like the compiler of Grassus work (Barrough), whom he cited, Banister did not use the term 'glaucoma.' To Grassus' concept of the incurable cataract, which included Gutta Serena, Banister added the clinical finding of hardness of the eye. Therefore, Banister appears to be the first European author to unite these concepts: the hard eye and incurable visual loss. Banister stated that a black cataract is the same as the Gutta Serena, which involves 'stopping of the Nerve Optics.' In other types of 'incurable' cataracts, 'all have the Nerves stopped, alteration of the color of the Crystalline humor, with a durosity or hardness of the whole Eye, and privation of sight.' The Gutta Serena is not likely to be cured if:

'First, if it be of long continuance. Secondly, if they see no light at all... Thirdly, if one feel the Eye by rubbing upon the Eyelids, that the Eye be grown more solid and hard, then naturally it should be. Fourthly, if one perceive no dilatation of the Pupilla, then there is no hope of a Cure' [20]. ${ }^{15}$

These concepts came together in the eighteenth century teachings of John Thomas Woolhouse (1666-1733), an English oculist who practiced in Paris. As noted previously [25], Woolhouse was intimately familiar with Guillemeau's treatise, its English translation, and Banister's Breviary (not to mention the texts of Read and the classic period). In fact, Woolhouse also refers to Bailey's work, and was aware that Barrough's work (Methode of Phisicke) was an adaptation of Grassus [6]. ${ }^{16}$ Woolhouse combined the two difficult-to-cure eye diseases: Guillemeau's glaucoma, due to a thick crystalline humor, and Banister's hard eye. According to Woolhouse, only a palliative cure of glaucoma was possible.

\footnotetext{
${ }^{13}$ Guillemeau [7] p. 171.

${ }^{14}$ Guillemeau [7] p. 171.

${ }^{15}$ Banister [20], no pagination.

${ }^{16}$ Woolhouse [6], pp. 196-197.
} 
In combining these three elements (the hard eye, difficulty in cure, and the word 'glaucoma'), Woolhouse gave birth to the modern conception of glaucoma. Woolhouse's teachings were recorded by 1707 in French $[26]^{17}$ and by 1721 in English [25]. Woolhouse's student, Johannes Zacharias Platner, MD (1694-1747) has traditionally been credited for being the first to call the palpably hard eye glaucoma in 1745 [27-29].

\section{CONCLUSION}

The writings or adaptations of Bailey, Grassus and Guillemeau reflected classical ophthalmic teachings which would continue to prevail for over a century. Although not previously recognized by scholars, Two Treatises incorporates all three of these primary texts. Composite texts such as Two Treatises or those by Banister and Read, and continued citation and development of the early concepts in the eighteenth century, demonstrated the enduring influence of the primary ophthalmic texts of 1580 s Britain.

\section{CONFLICT OF INTEREST}

The authors confirm that this article content has no conflict of interest.

\section{ACKNOWLEDGEMENTS}

The authors would like to thank Brian Vickers, PhD for assistance in researching the history of Walter Bailey's treatise. Partially supported by NIH Center Core Grant P30EY014801 and Research to Prevent Blindness Unrestricted Grant to the University of Miami.

\section{APPENDIX}

The origins of Two Treatises Concerning the Preseruation of Eie-sight.

The origins of Two Treatises Concerning the Preseruation of Eie-sight, published in 1616 [18], 1626 [19], and 1633 are interesting (Table 1). The text purports to be taken from Jean Fernel (1497-1558) and Jean Riolan, the elder, (1538-1605). Some have noted that neither Fernel nor Riolan published a strictly ophthalmic text [30], and have suggested this origin was claimed merely to lend credence to the work [5]. Others have suggested that Riolan's Ars Bene Medendi, first published in 1601, was the source. Our lineby-line analysis suggests that the author could have used Ars Bene Medendi [31], or another by Riolan from 1610 [32], which had identical passages on the eye. Methode of Phisicke, the adaptation of Grassus' text, is the source of the section on needling the cataract [5].

Finally, we have identified that the sections on hypopyon, amaurosis, ophthalmia, and pathophysiology of cataract are taken directly from Worthy Treatise, the translation of Guillemeau [7]. Both the Guillemeau translation and Two Treatises specifically cite Paré as the authority of paracentesis for hypopyon.

Also consider the introductory definitions for cataract for Fernel: 'Suffusio est humoris præter naturam' [33].

\footnotetext{
${ }^{17}$ Woolhouse [26], pp. 19, 35-36
}

for Riolan: 'Suffusio notha imprimis distinguenda est, appello notham quando fit vaporibus à ventriculo ad oculos ascendenti-bus' [32],

and for Guillemeau: 'Hypochyma est une acumulation d'humeur superflu' [7]. ${ }^{18}$

The word "heape" is clearly not a direct borrowing of prior French or Latin expressions. Both the translation of Guillemeau [7] ${ }^{19}$ and Two Treatises $[18]^{20}$ state that a cataract is 'an heape of superfluous humors.' How distinctive is this expression? In the 44,000 pre- 1700 works in the Early English Books Online Text Creation Partnership [14], these are the only two works to use this expression in any context. The association with Fernel comes merely from the fact that Guillemeau draws upon Fernel's understanding of cataract pathophysiology. Although online bibliographies (Google books, worldcat.org, and the Text Creation Partnership [14]) list Fernel as a coauthor of Two Treatises, we suggest that Guillemeau and Hunton should be substituted.

The work is preceded by a dedication signed I.B., assumed to be the London bookseller John Barnes. The title page declares that the work was printed in Oxford by Joseph Barnes, for John Barnes, who was his son. Indeed, John Barnes received legal title and published Bailey's work in 1602 [17]. ${ }^{21}$ However, by 1895 it was noted that the woodcuts were consistent with publication in London, as opposed to Oxford [30]. More recent scholarship has specifically identified George Eld as the printer [10]. ${ }^{22}$ It may seem unlikely that John Barnes would participate in a scheme to forge his father's imprint, but scholars do consider that a possibility [10]. ${ }^{23}$ John Barnes was known to have a bookshop for George Eld. ${ }^{24}$

The identity of the translator and editor are unknown. John Barnes did not specialize in medical works, and in the dedication identifies himself as the publisher and thanks 'the Authors' [18]. Creation of the work involved translation from Latin and an understanding of ophthalmologic works.

\section{REFERENCES}

[1] Bailey W. A briefe treatise touching the preservation of the eie sight, consisting partly in good order of diet, and partly in use of medicines. Robert Waldegrave. Eliot's Court Press: London 1586.

[2] Wood CA. The first English monograph on ophthalmology. Bull Soc Med History Chicago 1920; 2: 146-57.

[3] Barrough P. The methode of phisicke conteyning the causes, signes, and cures of invvard diseases in mans body from the head to the foote. Thomas Vautroullier dwelling in the Blacke-friars by Lud-gate: London 1583.

[4] Shklar G. Philip Barrough, Elizabethan physician with the first English book on medicine. J Hist Dent 2004; 52: 55-9.

[5] Eldredge LM. The English vernacular afterlife of Benvenutus Grassus, ophthalmologist. Early Sci Med 1999; 4:149-63.

[6] Woolhouse JT. A Treatise of ye Cataract \& Glaucoma. Royal Society of Medicine: London 1721; pp. 196-7.

[7] Guillemeau J, Hunton A, Bailey W. A worthy treatise of the eyes contayning the knowledge and cure of one hundred and thirtene diseases, incident vnto them: first gathered \& written in French, by

\footnotetext{
${ }^{18}$ Guillemeau [7], p. 78.

${ }^{19}$ Guillemeau [7], p. 156.

${ }^{20}$ Bailey [18], p. 50.

${ }^{21}$ Bailey [17]. Short Title Catalog number 1195.

${ }^{22}$ Bailey [18] under Short Title Catalog number 1196 in reference [10].

${ }^{23}$ Pollard [10], pp. 13-14.

${ }^{24}$ Pollard [10], pp. 58.
} 
Iacques Guillemeau, chyrurgion to the French King, and now translated into English, together with a profitable treatise of the scorbie; \& another of the cancer by A.H. Also next to the treatise of the eies is adoiyned a work touching the preseruation of the sight, set forth by VV. Bailey. D. of Phisick. Printed by Robert Waldegraue for Thomas Man and VVilliam Brome: London 1587.

[8] Guillemeau J. Traité des maladies de l'oeil: qui sont en nombre de cent treize, ausquelles il est subject. Chez Charles Massé, au Clos Bruneau à l'enseigne de la Pyramide: Paris 1585; p.78. Available from: http://archive.org/details/traitdesmaladi00guil [Last accessed Sep 10, 2013].

[9] Pollard AW, Redgrave GR, Pantzer KF. A short title catalogue of books printed in England, Scotland, \& Ireland and of English books printed abroad 1475-1640. $2^{\text {nd }}$ ed. The Bibliographical Soc. Oxford University Press: London 1986; pp. 55-546.

[10] Pollard AW, Jackson WA, Pantzer KF. A short-title catalogue of books printed in England, Scotland, and Ireland and of English books printed abroad: 1475-1640. A printers' \& publishers' index. $3^{\text {rd }}$ ed. Bibliographical Soc: London 1991; pp. 13-176.

[11] Hirschberg J, Blodi FC. The History of Ophthalmology. Vol. 2. The Middle Ages; The $16^{\text {th }}$ and $17^{\text {th }}$ Centuries. J.P. Wayenborgh Verlag: Bonn 1985; pp. 318-22.

[12] Power D. Dr. Walter Bayley and his works, 1529-1592. Royal Medical and Chirurgical Society. London 1907; Available from: http://archive.org/details/drwalterbayleya00powegoog [Last accessed Sep 10, 2013].

[13] The Oxford English Dictionary Online. December 2011 update. Available from: www.oed.com [Last accessed Sep.10, 2013].

[14] Early English Books Online Text Creation Partnership. Available from: http://quod.lib.umich.edu/e/eebogroup/ [Last accessed Sep $10,2013]$.

[15] Gale Cengage Learning Eighteenth Century Collections Online. Available from: http://www.galegroup.com [Last accessed Sep 10, 2013].

[16] Voyant Tools. Available from: http://voyant-tools.org/ [Last accessed April 22, 2013].

[17] Bailey W. A briefe treatise touching the preservation of the eie sight consisting partly in good order of diet, and partly in use of medicines. Ioseph Barnes, Printer to the Vniversitie: Oxford 1602.

[18] Bailey W, Barnes J, Riolan J. Two treatises concerning the preseruation of eie-sight. The first written by Doctor Baily sometimes of Oxford: the other collected out of those two famous phisicions Fernelius and Riolanus. By Ioseph Barnes [i.e. G. Eld], for Iohn Barnes: Oxford [i.e. London] 1616

[19] Vaughan W, Bailey W, Barnes J, Riolan J. Directions for health, naturall and artificiall deriued from the best phisitians, as well moderne as antient. Whereunto is annexed two treatises of the Eyes. The first by doctor Baily, the other collected out of Fernelius and Riolanus. Printed by Iohn Beale for Francis Williams: London 1626.

[20] Banister R, Guillemeau J, Hunton A, Weyer J, Textor B, Bailey W. A treatise of one hundred and thirteene diseases of the eyes, and eye-liddes. The second time published, with some profitable additions of certaine principles and experiments. By Felix Kyngston, for Thomas Man, dwelling in Pater-noster-row, at the signe of the Talbot: London 1622.

[21] A D B. Benevenutus Grassus of Jerusalem. Canad Med Assoc J 1930; 22: 850-1.

[22] Leffler CT, Schwartz SG, Stackhouse R, Davenport B, Spetzler K Evolution and impact of eye and vision terms in written English. JAMA Ophthalmology 2013; 131:1625-31.

[23] Read W. A short but exact account of all the diseases incident to the eyes. $2^{\text {nd }}$ ed. J. Baker: London 1710.

[24] Digby K. Two treatises in the one of which the nature of bodies, in the other, the nature of mans soule is looked into in way of discovery of the immortality of reasonable soules. Gilles Blaizot: Paris 1644; p.113.

[25] James RR. Woolhouse (1666-1733-4). Br J Ophthalmol 1934; 18 : 194-217.

[26] Woolhouse JT, LeCerf C. Dissertations sçavantes et critiques de monsieur de Woolhouse, sur la cataracte et le glaucome. Bonaventure de Launoy: Offenbach 1717; pp. 19-36. Available from: http://www2.biusante.parisdescartes.fr/livanc/index.las? $\operatorname{cote}=30850$ $\& \mathrm{do}=$ chapitre [Last Accessed Sep 10, 2013].

[27] Terson MA. Les premiers observateurs de la durété de l'oeil dans le glaucome. Archives d'Ophtalmologie 1907; 625-30.

[28] Hirschberg J, Blodi FC. The History of Ophthalmology. Vol 6. The First Half of the Nineteenth Century (Part Two). J. P. Wayenborgh Verlag: Bonn 1986; pp. 154-64.

[29] Sorsby A. Hardness of the eye: an historical note. Br J Ophthalmol 1932; 16: 292-5.

[30] Falconer Madan. The early Oxford Press: a bibliography of printing and publishing at Oxford, 1468-1640. Oxford University Press: Oxford 1895; p.105.

[31] Riolan J. Ars bene medendi. A. Perier: Paris 1618.

[32] Riolan J (the elder). Ioannis Riolani ambiani medici parisiensis, viri clarissimi opera omnia. Ex officina Plantiniana: Paris 1610 Available from: http://www2.biusante.parisdescartes.fr/livanc/?cote $=00326 \& d o=$ chapitre [Last accessed Sep 10, 2013].

[33] Fernel J. Medicina. J. Stoer: Paris 1578; 262. http://www2.biusante. parisdescartes.fr/livanc/index.las? $\mathrm{p}=268 \&$ cote $=00391 \mathrm{a} \&$ do $=$ page [Last accessed Sep 10, 2013]. 